5. Голубкова Н. Л. Роль молодіжних організацій та рухів у становленні активної громадянської позиції американських школярів / Н. Л. Голубкова // Вісник Житомирського державного університету ім. І. Франка. - 2008. - № 42. - С. 69-73.

6. Демократія: антологія / упор. О. Проценко. - К. : Смолоскип, 2005. - 1108 с.

7. Мережа M 18: вибори для дітей і молоді. URL: https://m18.org.ua (дата звернення: 01.10.2019).

8. Мошер Р. Воспитание гражданина: демократическиешколы/ Р. Мошер, Р. Кении, Э. Гаррод;пер. с англ. ; под общ. ред. Т. Э. Балуян, Е. Я. Мигунова, Е. И. Яковлева. - М. : Народное образование, 1996. - 232 с.

9. Переглянута Свропейська хартія про участь молоді в місцевому та регіональному житті. URL: https:// rm.coe.int/168071b58f (дата звернення: 01.10.2019).

10. Петров О. В. Соціалізація школярів у процесі розвитку учнівського самоврядування / О. В. Петров, В. Ф. Петров // Таврійський вісник освіти. - 2016. № 1. - C. 41-47.

11. Петрочко Ж. В. Участь у житті суспільства як прояв соціальної ініціативності підростаючої особистості / Ж. В. Петрочко // Наукові записки Тернопільського національного педагогічного університету ім. В. Гнатюка. - 2013. - № 3. - С. 47-51. - (Серія «Педагогіка»).

12. Політична освіта в Україні: проблеми та перспективи розвитку / за заг. ред. С. Г. Рябова. - К. : Інститут громадянської освіти НаУКМА, 2005. - 44 с.
13. Ремех Т. О. Сутність і структура громадянської компетентності учня нової української школи / Т. О. Ремех // Український педагогічний журнал. 2018. - № 2. - С. 34-41.

14. Скажи своє слово : посібник із Переглянутої Європейської хартії про участь молодих людей у місцевому та регіональному житті. URL: https://rm.coe. int/have-your-say-manual-ukr/1680789a84 (дата звернення: 04.10.2019).

15. Теорія і практика виховання культури демократизму учнів старших класів загальноосвітніх навчальних закладів : автореф. дис. на здобуття наук. ступеня д-ра пед. наук : 13.00.07 / Г. А. Назаренко; Нац. акад. пед. наук України, Ін-т проблем виховання. Київ, 2016. - 44 с.

16. Тищенко О. I. Деякі умови формування громадянського виховання учнів / О. І. Тищенко // Педагогіка формування творчої особистості у вищій і загальноосвітній школах. - 2016. - Вип. 46. - С. 170-175.

17. Perry-Hazan L. The framed right to participate in municipal youth councils and its educational impact / L. Perry-Hazan, T. Nir // Children and Youth Services Review. - 2016. - № 69. - C. 174-183.

18. Youniss I. What we know about engendering civic identity / I. Youniss // American Behavioral Scientist. -1997. - Mar./Apr. - Vol. 40. - № 5. - P. 620-631.

Дата надходження до редакиії: 07.10.2019 p.
УДК 37.015.31:17.022.1 - 021.414

DOI: 10.37026/2520-6427-2019-100-4-149-153

\section{Тетяна КОВБАСЮК,}

кандидат педагогічних наук,

доиент кафедри педагогіки, психологї та

корекиійної освіти Рівненського ОІППО

\title{
МОРАЛЬНІ ЦІННОСТІ СУЧАСНОГО ВИХОВАННЯ
}

У статті проаналізовано моральні иінності сучасного виховання. Висвітлено основні теоретичні положення щзодо змісту і сутності прощесу виховання моральних ичінностей зростаючої особистості, зокрема на основі аналізу філософських, педагогічних та психологічних праць провідних вітчизняних науковців встановлено, щзо утвердженню моральності сприяє багаторазове здійснення самостійного морального вибору, здатність покладатися на себе $i$ відповідати за свої вчинки. Розкрито значення понять «иінності», «иіннісні орієнтаиії», «моральність», «моральні иінності». Особливу увагу акиентовано на ролі сім'ї як соиіальному інституті та важливому компоненті освітнього процесу.

Ключові слова: иінності, мораль, моральність, моральні изінності, моральна позииія, иіннісна орієнтація, структура моральних иінностей, моральна самосвідомість, виховання.
В статье проанализированы нравственнье иенности современного воспитания. Освещуены основные теоретические положения относительно содержания и сущиности проиесса воспитания нравственных иеенностей растущей личности, в частности на основе анализа философских, педагогических и психологических работ ведущих отечественньх ученьх установлено, что утверждению нравственности способствует многократное осуществление самостоятельного нравственного выбора, способность полагаться на себя и отвечать за свои поступки. Раскрыто значение понятий «ценности», «ценностные ориентации», «нравственность», «моральные иенности». Особое внимание акцентировано на роли семьи как сочиального института и важного компонента образовательного прочесса.

Ключевые слова: иенности, мораль, нравственность, моральные иенности, нравственная позиция, цеенностная ориентация, структура моральных цеенностей, моральное самосознание, воспитания. 
The article deals with the basic theoretical position of essence the process of education of moral values of growing personality on elaboration of philosophical, pedagogical and psychological researches.

It has been revealed the concepts of «values», "value orientations», "morality», "moral values» in the context of consideration regarding the formation of the system of moral self-awareness, activity, increase of the level of self-knowledge, self-esteem and internalization of social and moral values of growing personality.

Some scientific positions on the disclosure and study of the morality, moral position of the individual and its universal values are distinguished. On the basis of the analysis of scientific researches, components of the structure of moral values are determined: moral will, moral conscience, self-esteem of the individual, moral motives.

Attention is drawn on the role of the family as a social institution which is an important component of the educational process also the core tasks of the family and educational institution in shaping the moral values of the growing personality (introducing it into the world of moral relationships, revealing the cultural meanings of moral values, focusing on humane, good, honest, fair relations and actions, suggestions of good behaviors, analysis of proper behavior, analysis the right moral choice).

It has been shawn the new educational paradigm and scientific categories, in particular: act life, higher meanings, meaningful sphere, spirituality as an expression of spirit, spiritual personality, spiritual self-consciousness, and that moral values are inherent only to man, their bearer is spiritual intention (orientation) which is subject to ethical evaluation.

On analysis of leading educators and psychologists it has been established, that the assertion of morality is facilitated by repeated exercise of independent moral choice, the ability to rely on oneself and be responsible for one's actions.

Key words: values, value, morality, morality, moral values, moral position, value orientation, structure of moral values, moral consciousness, education.

Постановка проблеми. Актуальність проблеми формування моральних цінностей дітей та молоді набуває сьогодні особливої ваги, адже переглядаються ціннісні суспільні орієнтації, розробляються нові підходи до формування духовно-морального потенціалу особистості як джерела добробуту самої людини та умови ії особистісного зростання зокрема і суспільного розвитку загалом.

У Концепції «Нова українська школа» зазначено, що процес виховання - це невід'ємна складова всього освітнього процесу, що орієнтується на загальнолюдські цінності, зокрема морально-етичні, національні та соціально-політичні. Змістове наповнення сучасного виховання орієнтоване передусім на формування ціннісних ставлень і суджень особистості, що слугують базою для щасливого особистого життя й успішної взаємодії із суспільством [8]. Зокрема, визначають цінності та ставлення особистості до себе і людей, до суспільства та держави, природи й власного здоров'я, праці та мистецтва, тобто до соціального та природного довкілля та самої себе. Нова школа повинна плекати українську ідентичність, виховувати не лише відповідальність за себе, а й за розвиток $\mathrm{i}$ добробут країни й людства в цілому.

У сучасному українському суспільстві на сьогодні мають місце руйнівні процеси, що спостерігаються в соціальному житті та негативно впливають на процес розвитку суспільної свідомості людей у сфері їх моральних відносин. Приміром, поглибилися прояви деформації в системі ціннісних орієнтацій молодого покоління; в життєвому просторі простежується зниження вартості етичних норм і принципів, що врегульовують поведінку особистості. В молодих людей посилюються егоїстичні тенденції, знижується рівень розвитку моральних цінностей, почуттів, спостерігається викривлення моральної мотивації. В учнівському середовищі зростає злочинність, озлобленість, нігілістичне ставлення до принципів моралі: спостерігається крайній егоцентризм, відчуття вседозволеності, низький рівень культури спілкування, небажання брати на себе відповідальність, недостатня сформованість національної самосвідомості, втрата життєвого оптимізму та інші негативні прояви.

Таке становище викликане і глобалізаційними процесами, за яких світ став більш уніфікованим, коли за модель розвитку часто намагаються брати західні зразки. Сьогодення пропонує різні канали соціалізації особистості: телебачення, Інтернет, рекламу, ігрові технології тощо, які впливають на процеси формування зростаючої особистості, іiі адаптацію в суспільстві. Вони поширюють і популяризують певні зразки, стилі та норми поведінки, моделюють і впроваджують у масову свідомість образ реальності, до якої необхідно прагнути. Подібна інформація, що є джерелом нових знань, являє собою приховану небезпеку як для підростаючого покоління, так і суспільства в цілому, а як наслідок - нівелюється істинна цінність людини. Молоде покоління, яке, на жаль, не має стійких ідеологічних, моральних та духовних цінностей, прагне до способу життя, який нав'язується ззовні.

Мораль, як відомо, покликана духовно єднати суспільство; орієнтує особистість на краще. При цьому моральна людина, навіть стикнувшись із безумовною необхідністю вчинити щось проти власної совісті, демонструє свободу людського духу, право вибору. Сучасне виховання грунтується на гуманістичній особистісно орієнтованій парадигмі, $є$ наскрізним процесом та носить випереджувальний характер. Воно покликане зупинити соціальну деградацію, стати засобом відродження культури, стимулом пробудження моральних чеснот і якостей, інструментом забезпечення позитивної самореалізації, вироблення особистісної відповідальності за власний життєвий проєкт та розвиток суспільства загалом.

Пріоритет у вихованні моральних цінностей визначається тим, що вони є регуляторами поведінки особистості та охоплюють різні аспекти життя людини.

Аналіз наукових досліджень і публікацій. Поняття «цінності», «цінність», «мораль», «моральність» функціонують як у філософській, так і педагогічній та психологічній науках. Існують різні погляди на природу та зміст виховання моральних цінностей. Аналіз ї сутностей знаходимо в працях філософів-класиків (Платон, Аристотель, І. Кант, Г. Гегель, Г. Лотце); психологів та педагогів (І. Бех, Л. Виготський, Д. Леонтьєв, О. Леонтьєв, М. Рокич); сучасних філософів, соціологів, культурологів (С. Анісімов, В. Барулін, М. Каган, Л. Мікешин, Б. Орлов, В. Сагатовський).

Так, С. Анісімов характеризує цінності як позитивне значення об'єкта для людини з точки зору того, наскільки він може задовольнити потребу, 
що виникла в його життєдіяльності [2, с. 67]. М. Каган зазначає, що цінність - це внутрішній, емоційно освоєний суб'єктом орієнтир діяльності людини. Цінності скеровують, орієнтують, регулюють стосунки людей, а сприятливе середовище для засвоєння цінностей $є$ важливим [6, с. 164]. С. Анісімов і М. Каган пропонують розглядати цінність у поєднанні $з$ ціннісним ставленням та етичною оцінкою, адже ціннісне ставлення допомагає визначити значимість і смисл об'єкта для суб'єкта (тобто його цінність); оцінка дозволяє перевести результати ставлення в емоційно-інтелектуальну площину [6, с. 111].

Значний внесок у теорію морального розвитку особистості зробили українські вчені І. Бех, А. Богуш, Г. Васянович, С. Гончаренко, С. Карпенчук, О. Киричук, Н. Ковтун, О. Кононко, О. Сухомлинська, П. Щербань та ін. У своїх наукових розвідках вони акцентують увагу на засвоєнні людиною норм моралі як сукупності правил і перехід їх у площину вчинків. Наприклад, Н. Ковтун зазначає, що «в контексті цього мораль постає як специфічна сфера соціальної активності, для якої характерна єдність об'єктивної соціальної необхідності та суб'єктивно зорієнтованої свободи волі індивіда або соціальноїгрупи. Всупереч тому, що моральні цінності виховуються через соціальний примус, конкретна моральна поведінка індивіда, як втілення його соціальної активності, виходить із автономії духу і свободи волі» $[7$, с. 244].

В основу поняття «цінність» покладено наявність у певних предметах, явищах, довколишній природі ознак і властивостей, що відображають їхню значущість для людини зокрема чи суспільства загалом, тобто становлять актуальну потребу особистості.

Мета статті - розкрити основні теоретичні положення щодо змісту та сутності процесу виховання моральних цінностей зростаючої особистості; охарактеризувати моральні цінності сучасного виховання.

Виклад основного матеріалу. Цінності $\epsilon$ основою культури кожного народу, нації, суспільства. Сучасний дослідник цінностей, автор концепції культурних вимірів, голландський учений Г. Хофстеде, переконаний, що вони знаходяться на найглибшому рівні серед важелів прийняття рішень, формують переконання особистості та мотивацію ï вчинків. Саме до цінностей, на думку відомого американського соціолога Т. Парсонса, звертаються люди з метою остаточного обгрунтування своїх дій. Цінності виходять за межі конкретних ситуацій (тобто можуть вирішуватися особистістю під впливом інтересів і переконань), адже визначають головні цілі та сенс життя та найяскравіше проявляються для людини або соціуму в кризові моменти $[1$, с. 3$]$.

Цінності є глибинними смисложиттєвими орієнтаціями особистості, адже визначають цілі їі життя й переконання. Вони вільно обираються нею як власні життєві устремління, кредо та переконання і не потребують примусу з боку певних осіб чи інституційних установ. Цінності передусім існують як внутрішній обов'язок людини вчиняти чесно, справедливо та достойно.

Моральні цінності є потужним регулятором поведінки та взаємовідносин людей. Коли норми права в державі перетворюються на цінності, це означає, що людина вчиняє не за примусом, а за внутрішнім обов'язком, тобто право трансформується в мораль, що є високим показником розвитку суспільства.
Моральні цінності відіграють важливу роль у суспільному житті, бо мораль завжди передбачає врахування особистістю інтересів та цінностей іншої людини й усього суспільства загалом; вони визначають смислові орієнтири життя людей, соціальних груп, держав і націй.

У вихованні зростаючої особистості важливо з'ясувати суспільну сутність людини, яка вступає в різноманітні відносини з метою задоволення власних потреб. Вагомим доробком у цьому вважаємо педагогічну спадщину В. Сухомлинського, в якій виокремлено проблему моральності як чільну у процесі виховання особистості. «Я прагну до того, - наголошував видатний педагог-гуманіст, - щоб діти зрозуміли велику моральну цінність: людина утверджується у світі не тільки як істота, що мислить і відчуває, а насамперед як жива ланка у вічному ланцюгу поколінь; цей ланцюг поєднує минуле покоління 3 майбутнім. Чим більше шанує людина пам'ять своїх батьків, дідів і прадідів, тим глибше вона відчуває свою відповідальність за майбутнє» [9, с. 9].

Цінності відіграють важливу роль у формуванні особистості. Надбання цінностей - неабиякий здобуток кожної особистості, а також створення образу майбутнього й оцінка діяльності людини з їі морального боку. Власна система ціннісних орієнтацій особистості виступає програмою іiі особистісного зростання впродовж життя. Структура цінностей кожної людини, як-от характер, вірування, прагнення тощо, відображає природну сутність особистості, тобто те, якою людина $є$, а не лише бажає себе бачити.

Ціннісна орієнтація може бути спрямована як на справжні, високі цінності, так і на хибні. Ступінь моральності особистості, iї духовності значною мірою залежить від укоріненості в їі психіці стійких орієнтацій на гуманні цінності та ідеали.

Мораль є свідченням певного рівня розвитку, духовної зрілості людини, характеру їі відносин з іншими людьми і світом. Моральність - це правила, які визначають поведінку та їх виконання, духовні й душевні якості, необхідні людині в суспільному житті. Моральність включає в себе усі норми і принципи, які формують зростаючу особистість і впливають на становлення людини. Рівень моральності надзвичайно впливає на становлення дорослої особистості, яка поважає себе та оточуючих.

Сьогодення потребує пошуку нових підходів в організації освітнього процесу, впровадження освітніх, зокрема й виховних, технологій, що сприятимуть моральній активності особистості, для якої поняття справедливості, милосердя, доброзичливості, толерантності, совісті, миролюбності, готовності допомогти іншим, ввічливості, делікатності, тактовності мають стати ціннісними орієнтирами. Сучасний педагог буде успішним лише в тому випадку, якщо володітиме неабияким умінням зачаровувати вихованців щирістю, альтруїзмом, любов'ю до людей. Традиційна теорія і методика виховання з їх принципами й засобами не відповідає теперішнім виховним цілям. Усі особистісно-перетворювальні інструменти переглядаються, а інноваційні - апробуються.

За визначенням академіка I. Беха, «ми переживаємо справжній ренесанс у педагогіці: вона сповна одухотворюється. Це стало можливим завдяки її глибинному психологічному супроводу... Йдеться про нову виховну парадигму, зокрема вводяться нові наукові категорії: вчинкове життя, вищі смисли, смислоцінна сфера, духовність як вираження духу, духовна особистість, духовна самосвідомість тощо» [4, с. 9-10]. 
Сучасна освіта орієнтована на особистість, внаслідок чого метою освітнього процесу є розкриття й розвиток індивідуальності кожної дитини на основі формування іiі особистісної культури. Чинником у характеристиці культури особистості є її взаємодія із соціумом, опанування моральних цінностей і почуттів. Для особистісного зростання потрібні відповідні соціальні умови й цілеспрямоване виховання.

Дитина не народжується ні моральною, ні аморальною, ні доброю, ні злою. Які моральні цінності у неї розвинуться, залежить від ставлення до неї оточуючих, від методів виховання, від соціального оточення, в якому перебуває особистість, а також від сімейного виховання. За умови правильного виховного впливу, належної організації освітнього середовища на засадах співпраці й взаємодопомоги у вихованців формуються суспільні мотиви, що спонукають дотримуватися прийнятих моральних норм поведінки не за зовнішнім примусом, а з власної ініціативи, за внутрішнім переконанням.

Завдання педагогічних колективів, батьківської громади - навчити дитину взаємодіяти 3 іншими людьми, собою, навколишнім світом на основі моральних цінностей, гармонії. Така модель освітнього середовища покликана базуватися на засадах демократизму й гуманізму, сприяти створенню умов для особистісного розвитку, самопізнання, самореалізації зростаючої особистості.

Дослідник В. Кукушин стверджує, що моральна позиція особистості та іiі загальнолюдські цінності, сформовані в дошкільному віці, згодом перетворюються на характер людини. Ось чому саме сім'я як соціальний інститут $\epsilon$ важливим компонентом освітнього процесу в справі формування моральних цінностей зростаючої особистості. Вчений виділяє такі типи моральних цінностей, як: універсальні (повага, чесність, співчуття); неуніверсальні (обов'язки щодо релігії, школи, сім'ї). Крім того, він зазначає: «Суспільство має захистити молоде покоління від морального занепаду, інакше таке суспільство - це країна без майбутнього» [5, с. 201, 231]. Отже, моральний захист дітей і молоді є ключовою проблемою XXI століття, розв'язання якої можливе лише за спільної взаємодії сім’ї, освітнього закладу та громадськості.

У процесі виховання відбувається формування менталітету особистості, iї кругозору, думок, норм і правил поведінки в побуті та суспільстві, саме з цього складається стиль їі життя. Виховання впливає на становлення внутрішнього і зовнішнього світів особистості, через уявлення про відповідні поняття та істини, які їй вдалося отримати від батьків, вихователів, педагогів, ровесників, із книг тощо. Одним зі стрижневих завдань сім'ї та закладу освіти щодо формування моральних цінностей зростаючої особистості є прагнення ввести іiі у світ моральних стосунків, розкрити красу і культурні сенси моральних цінностей, орієнтувати на гуманні, добрі, чесні, справедливі стосунки і вчинки, запропонувати зразки належної поведінки, стимулювати внутрішню роботу особистості над своїми вчинками, допомогти дитині зробити правильний моральний вибір.

Структура моральних цінностей передбачає такі складові: моральна воля; моральна совість, яка у поєднанні з логічною та естетичною совістю забезпечує прояв відповідальності в думках, почуттях, поведінці; самооцінка індивіда, що забезпечує вимогливість не лише до інших, а й до себе; моральні мотиви, які повинні бути загальнозначущими і забезпечувати досягнення моральних цілей [10, с. 106-107].
М. Каган до цінностей індивідуального суб'єкта, що характеризують його свідомість і самосвідомість, відносить моральні цінності (добро, справедливість, безкорисність, альтруїзм, благородство). Вони властиві лише людині, мають емоційну основу і виявляються у поведінці, спрямованій на іншу людину, а їх носієм $€$ духовна інтенція (спрямованість) поведінки, що підлягає етичній оцінці [6, с. 105-107]. Крім того науковець додає, що власне вчинок може підлягати утилітарній (як корисний або шкідливий) та естетичній (як красивий або потворний) оцінці, тоді як етичній оцінці підлягає не вчинок, а імпульси, мотиви, що зумовили його здійснення. Утвердженню моральності сприяє багаторазове здійснення самостійного морального вибору, здатність покладатися на себе i відповідати за свої вчинки, що призводять до формування певних потреб. При цьому ціннісним «інструментом» моральної свідомості є совість - внутрішня спонука до моральної дії [6, с. 111].

Висновки. 3 утвердженням гуманістично орієнтованої розвивальної виховної моделі на сучасному етапі розвитку суспільства пріоритетним має стати створення сприятливих умов для зайняття вихованцями активної позиції, набуття ними індивідуально-особистісної спрямованості. Сучасне розуміння гуманістичних цінностей освіти спирається на антропологічні й соціокультурні координати. У зв'язку 3 цим сутність гуманістичних цінностей в освіті варто розуміти таким чином: дитина - головна педагогічна цінність, а отже, не дитину треба пристосовувати до системи освіти, а освіті - до неї [3, с. 36-37]. Зважаючи на це, пріоритетним має стати формування системи моральної самосвідомості, ціннісного ставлення дітей та учнівської молоді не лише до самих себе як особистостей, до власної свободи, відповідальності, людської гідності, совісті, самодостатності, а й до соціального оточення [4, с. 7].

Педагоги-практики, вихователі, всі причетні до виховання підростаючої особистості мають ураховувати позитивний досвід людства, аби не втратити власні історичні надбання та національну специфіку, а потім не надолужувати згаяне у безпрецедентній прогресії. Зокрема, стимулювати в школярів власні психологічні ресурси, підвищувати їхній рівень самопізнання, самоповаги, активізувати реалізацію сутнісних сил, інтеріоризацію суспільних та моральних цінностей. Саме це, на нашу думку, сприятиме появі серед молоді відповідальних, високоморальних громадян-патріотів, які у майбутньому відстоюватимуть національні інтереси, забезпечуватимуть продукування прогресивних ідей та їх реалізацію.

\section{СПИСОК ВИКОРИСТАНОЇ ЛІТЕРАТУРИ}

1. Амельченко Н. А. Цінності об’єднаної Європи / Н. А. Амельченко. - К. : ГО «Лабораторія законодавчих ініціатив», 2013. - 42 с. - Режим доступу : https:// parlament.org.ua/upload/docs/European_Values.pdf

2. Анисимов С. Ф. Введение в аксиологию. Учебное пособие для изучающих философию / С. Ф. Анисимов. - М.: Современные тетради, 2001.$128 \mathrm{c}$.

3. Бех І. Д. Виховання особистості : в 3 кн. / І. Д. Бех. - К. : Либідь, 2003. - Кн. 3 : Особистісноорієнтований підхід : науково-практичні засади. $272 \mathrm{c}$. 
4. Бех І. Д. Особистість на шляху до духовних цінностей : монографія / І. Д. Бех. - Київ - Чернівці : Букрек, 2018. - 296 с.

5. Срмак Г. В. Аналіз морального виховання у працях радянських $\mathrm{i}$ сучасних дослідників : історичний аспект / Г. В. Срмак // Науковий вісник Мелітопольського державного педагогічного університету. Серія : Педагогіка. - 2014. № 1. - C.261-265. URL : http://nbuv.gov.ua/UJRN/ Nvmdpu 2014147

6. Каган $\overline{\mathrm{M}} . \overline{\mathrm{C}}$. Философская теория ценности / М. С. Каган. - Санкт-Петербург : ТОО ТК «Петрополис», 1997. - 205 c. - URL : https://www.logicbooks. info/sites/default/files/kagan. filosofskaya teoriya cennosti.pdf (дата звернення: 10.09.2019).

7. Ковтун Н. М. Співвідношення морального і вольового у контексті дослідження соціальної активності / Н. М. Ковтун // Гуманітарний вісник Запорізької державної інженерної академії : зб. наук. пр. / гол. ред. В. Г. Воронкова. - Запоріжжя : Вид-во ЗДІА, 2013. - Вип. № 53.

8. Нова українська школа. Концептуальні засади реформування середньої школи. URL : https:// www.kmu.gov.ua/storage/app/media/reforms/ukrainskashkola-compressed.pdf (дата звернення: 09.09.2019).

9. Сухомлинский В. А. Потребность человека в человеке / В. А. Сухомлинский. - 2-е изд. - М., 1981. $93 \mathrm{c}$.

10. Федорова М. А. Моральні цінності особистості : сутність поняття та основні характеристики / М. А. Федорова // Проблеми освіти: збірник наукових праць. - Спецвипуск. - Вінниця - Київ, 2015. C. 105-109.

Дата надходження до редакиії: 13.09.2019 p.

\section{БІБЛІОГРАФІЧНА СКЛАДОВА СИСТЕМИ ІНФОРМАЦІЙНОГО СУПРОВОДУ НАУКОВИХ ДОСЛІДЖЕНЬ ІЗ НАЦІОНАЛЬНО-ПАТРІОТИЧНОГО ВИХОВАННЯ}

У статті проаналізовано зміст $i$ структуру науково-допоміжного бібліографічного покажчика «Національно-патріотичне виховання в Україні» (2014-2018 рр.). Узагальнено основні наукові підходи до класифікації бібліографічних видань, наявних y бібліографічному науковому дискурсі та бібліографічній практииі. Зосереджено увагу на основних складових національно-патріотичного виховання: громадсько-патріотичному, військово-патріотичному та духовно-моральному вихованні. Констатовано, що формальні та змістові характеристики бібліографічних видань перебувають у постійній динамічній рівновазі, шзо обумовлено соиіальними, а також інформачійними чинниками розвитку суспільних відносин.

Ключові слова: науково-допоміжний бібліографічний покажчик, національно-патріотичне виховання, наукові дослідження, заклади освіти, військово-патріотичне виховання, військово-патріотичне виховання, духовно-моральне виховання.

В статье представлен анализ содержсания и структуры научно-вспомогательного библиографического указателя «Национально-патриотическое воспитание в Украине» (2014-2018 га.). Обобщчены основные научные подходы к классификации библиографических изданий, имеющихся в библиографическом научном дискурсе и библиографической практике. Сосредоточено внимание на основных составляющих национально-патриотического воспитания: общественно-патриотическом, военно-патриотическом и духовно-нравственном воспитании. Констатировано, что формальнье и содержстельные характеристики библиографических изданий находятся в постоянном динамическом равновесии, что обусловлено сочиальными, а также информационными факторами развития общественньх отношений.

Ключевые слова: научно-вспомогательный библиографический указатель, национально-патриотическое воспитание, научные исследования, учебные заведения, военно-патриотическое воспитание, военно-патриотическое воспитание, духовно-нравственное воспитание.

The Content and Structure of the scientific-auxiliary bibliographic Index «National patriotic Education in Ukraine» (2014-2018) are analyzed. The Relevance of the Chosen topic is Substantiated and the 